\title{
Editorial: Permian Extinctions
}

\author{
Robert A. Gastaldo ${ }^{1 *}$, Yukio Isozaki ${ }^{2}$, Evelyn Kustatscher ${ }^{3}$, Robert Reisz ${ }^{4}$ and \\ ShuZhong Shen ${ }^{5}$ \\ ${ }^{1}$ Department of Geology, Colby College, Waterville, ME, United States, ${ }^{2}$ Department of Earth Science and Astronomy, The \\ University of Tokyo, Tokyo, Japan, ${ }^{3}$ Museum of Nature South Tyrol, Bolzano, Italy, ${ }^{4}$ Ecology and Evolutionary Biology, University \\ of Toronto Mississauga, Mississauga, ON, Canada, ${ }^{5}$ State Key Laboratory for Mineral Deposits Research, School of Earth \\ Sciences and Engineering and Frontiers Science Center for Critical Earth Material Cycling, Nanjing University, Naniing, China
}

Keywords: triassic, extinction, paleobiology, paleoecology, Permian-Triassic boundary, permian

\section{Editorial on the Research Topic}

\section{Permian Extinctions}

The end-Permian mass extinction (EPME) is one of five deep-time intervals when Earth System perturbations resulted in extreme biodiversity loss, resetting the trajectory of life, and leading to a new biological world order. Erwin (1996) coined this critical interval in Earth history as the "Mother of Mass Extinctions." The available data at the time led the geoscience community to interpret a simultaneous collapse of terrestrial and marine ecosystems over a very short geologic time span, now believed to represent $<100 \mathrm{ka}$. Ecosystem demise was hypothesized to have been in response to extreme global warming, pushed past a tipping point by increasing concentrations of atmospheric greenhouse gasses. Atmospheric concentrations changed as a consequence of pulses of effusive gasses from the emplacement, over an $\sim 2$ million year timeframe (Burgess et al., 2014), of an extensive $\left(\sim 7 \times 10^{6} \mathrm{~km}^{2}\right)$ and voluminous $\left(\sim 4 \times 10^{6} \mathrm{~km}^{3}\right)$ flood basalt. That succession, the Siberian Traps, is a Large Igneous Province (LIP; Ivanov et al., 2013). Mounting geochemical, high-resolution geochronological, and magnetostratigraphic data, coupled with GCM modeling of the LIP effects on the Permian world (e.g., Frank et al., 2021), continue to reinforce the role(s) that the Siberian Traps played in this event. Multidisciplinary studies, incorporating these data into the rock record of various coeval geographic settings, has allowed further refinement in our understanding of the turnoverand-extinction patterns of the Late Paleozoic biosphere. Evidence continues to be unearthed about the extent and timing of perturbation and extinction in terrestrial and marine communities. There appears to have been a decoupling of biosphere responses, with terrestrial ecosystems affected earlier than the marine realm, but both are temporally linked to LIP activity in Siberia. It is upon this revised paradigm that a collection of 17 contributions, ranging from regional to global signals, has been compiled for the Permian-Extinction Research Topic.

One uncommon aspect about the current collection is the overwhelming number of contributions focused on the terrestrial fossil record of both plants and animals, challenging ideas perpetuated in the literature. A long-held tenet is the loss of major plant groups in the late Permian being replaced by newly evolved plant groups in the early Triassic. In fact, several Triassic macrofloral taxa, previously used as evidence for a post-extinction age assignment, have been recovered from Permian strata. Blomenkemper et al. report on the occurrence of what had been considered a unique and extinct Mesozoic plant group, the bennettitaleans. These authors report on macrofossils in the late Permian rocks of Jordan and unambiguous leaf remains from Shanxi Province, China. Their evidence pushes the group's earliest appearance in the fossil record even further back in time, to the early Permian. A common gymnosperm group of the Permian and Triassic, the peltasperms, often found as one element in diverse macrofloral assemblages. Feng et al. report on a late Permian, monotypic, stemand-leaf assemblage from the South China Block. This low latitude, tropical assemblage is preserved 
as charcoal. Similarly, Cai et al. report on dispersed charcoalified remains from latest Permian coals and siliciclastic rocks of southwest China. They describe seven different charcoal categories of tracheid-bearing and woody remains, along with vitrinite reflectance and stable-isotope $\delta^{13} \mathrm{C}$ data and suggest a turnover from rainforest to ground cover vegetation in the latest Permian. Reports of charcoal add to the growing evidence for the potential importance of wildfire on a regional scale during the EPME interval. However, the effects of wildfire on landscapes may be only a regional phenomenon.

Basalts comprise a large proportion of the rocks of the Tunguska Basin, Russia, a part of the Siberian LIP. Davydov and Karasev demonstrate the importance of understanding what effects volcanism had on vegetation on a regional scale in geochronometric context. These authors test the prevailing hypothesis that massive injections of greenhouse and poisonous gasses resulted in floral extirpation and extinction over the timeframe of the LIP. In contrast with other studies, they find an increase in floristic biodiversity in the earliest Triassic that peaks in the Middle Triassic when volcanism also peaks. When macrofloral assemblages are assessed on a global scale, though, Nowak et al. find that increasing seasonality on a continent is reflected in a reduction in earliest Triassic generic diversity. They relate these biome changes to shifts of environmental factors as a function of paleogeography, but note that the data are biased by taphonomy (absence of a succession of stage-level assemblages), paleolatitude, and depositional basin. This is particularly true for the earliest Triassic stage, the Induan. Schneebeli-Hermann takes another approach to evaluating diversity and ecological trends, by evaluating the spore-and-pollen assemblages in the paleosubtropics of Pakistan. Explanations to account for turnover or outright change in the plant-fossil record commonly invoke extinction as the mechanism. Yet, the loss of a regional assemblage can be equally explained as a shift in biomes between alternative stable states, in response the passage over one or more climate thresholds. Schneebeli-Hermann proposes such an explanation for abrupt regime shifts between Early Triassic gymnosperm-dominated and lycophyte-dominated vegetation, the latter characterized by the Isoetalean, Pleuromeia.

Pleuromeia is considered to be the "weed" of the Early to Middle Triassic, and is reported in both the macrofloral and palynological records across the globe. Looy et al. utilize these data and explore the taxon's physiology, autecology, and synecology, encompassing a wide array of life-history traits. They deduce that isoetaleans were not only stress-tolerant, but also a slow-growing weak competitor. And, the prevalence of isoetalean assemblages across almost all Early Triassic paleocontinents leads them to conclude that such assemblages are indicative of a global pattern of ecological deterioration. Latest Permian ecological deterioration in the Karoo Basin, South Africa, has been invoked by a cohort of authors to explain a purported turnover in vertebrate-fossil assemblages and the rise of its disaster taxon, the genus Lystrosaurus. Two contributions offer data confirming a different perspective on each.

The Karoo Basin hosts an extensive vertebrate-fossil record of Middle Permian to Late Triassic age, preserved in riverine, lake, and paleosol deposits. Although this succession has been reported to be "continuous" across the EPME, high-resolution sedimentologic and magnetostratigraphic data demonstrate ubiquitous missing sediment and time (e.g., Gastaldo et al., 2021). Much of what is missing are the fine-grained carbonate-nodule bearing soils that formed across these landscapes and were subsequently eroded. Gastaldo et al. (2020) reconstruct wet-dry and warm-cool oscillations using stable-isotope geochemistry of the recalcitrant soil nodules, concentrated as erosional remnants in fluvial channel-lag deposits. The fluctuation in latest Permian climate occurs across what has been considered, previously, as the pre-EPME Daptocephalus and the post-EPME Lystrosaurus declivis Assemblage Zone (AZ; Viglietti et al., 2021), where Lystrosaurus is designated a "disaster taxon" (Botha-Brink et al., 2016). The term disaster taxon was originally conceived for marine microorganisms that bloomed in the wake of a biological crisis and has become a term strongly attached to mass extinctions. It has been widely used by invertebrate paleontologists but rarely for terrestrial vertebrates. The iconic genus Lystrosaurus was for many years the only terrestrial vertebrate so designated. Modesto looks at the history of usage of the term "disaster taxon" and its application to that taxon. Recently, the diagnostic taxa identified as disaster taxa and used to define the $L$. declivis $\mathrm{AZ}$ are shown to be preserved in laterally equivalent rocks where the diagnostic taxa for the Daptocephalus AZ are preserved (Gastaldo et al., 2021). This is not to say that vertebrate turnover occurred during the Permian in the southern hemisphere.

Day and Rubidge provide field evidence for a middle Permian turnover of vertebrate assemblages in the Karoo Basin. The Capitanian mass extinction was first recognized in the oceans and correlated with another LIP event (Emeishan volcanism zenith, 263.5-261 Ma; Chen and Xu, 2021), although this continues to be debated. In South Africa, $\sim 74-80 \%$ of vertebrate generic richness is lost during an initial extinction interval which is overlain by a succession of a low diversity fauna and, ultimately, recovery. These authors, in part, link biodiversity loss to aridification, or the regional influence of tectonism on climate, and note that sedimentological evidence supports a stable paleoclimate. In contrast, extensive lacustrine conditions are reported by McLoughlin et al. in the aftermath of the EPME in Australia.

The uppermost coal in the Sydney Basin, Australia, signals the last occurrence of the Glossopteris flora in this part of Gondwana. It is overlain by a thin, distinct mudrock interval that can be traced across the basin for which McLoughlin et al. document its sedimentology, depositional setting, geochemistry, geochronology, and paleontology, placing the unit into a global paleoenvironmental perspective. Using this multidisciplinary data set, they find no evidence for marked aridification the formation of these lake deposits following the demise of the Glossopteris flora, 160-360 kyrs before the initial phase of marine extinctions which are linked to a perturbation in the carbon cycle.

Volcanism associated with the Siberian Traps perturbed the carbon cycle by introducing substantial volumes of $\mathrm{CO}_{2}$ and $\mathrm{CH}_{4}$, as evidenced by globally recorded $\delta^{13} \mathrm{C}$ trends in marine 
sediments. Saitoh and Isozaki report on the isotopic record of carbonate $\left(\delta^{13} \mathrm{C}_{\text {carb }}\right)$ across a $40 \mathrm{~m}$ thick interval in South China, encompassing the PTB. Here, they confirm the presence of a negative $\delta^{13} \mathrm{C}_{\text {carb }}$ shift identified by other workers and suggest that it is a feature indicating the collapse of primary productivity during the extinction interval. What is of interest is the repeated isotopic flux in the overlying lower Triassic rocks which these authors attribute a combination of factors. These include frequent changes in eustasy, the redox-sensitive proliferation of green sulfur bacteria, and continued methane pulses in the global $\mathrm{CH}_{4}$ cycle in the extinction's aftermath. These conditions appear to have affected sponge and associated microbial sponge communities.

Baud et al. present new insights into sponge and microbial sponge communities in two Iranian PTB localities where sponge fibers and digitate sponge-microbialite buildups, in which similar fibers and spicules, are preserved. The shallow marine buildups range from $\mathrm{dm}-\mathrm{m}$ scale elongate bowls to open bowl-shapes in which mounds formed with clotted textures. The authors note that sponges commonly colonize modern reefs after the extirpation of metazoans. They argue for the regional EPME sponge takeover, first identified in Armenia and NW Iran, extending into Central Iran and having continued into the earliest Triassic, providing a datum in the Neo-Tethys. Outside of the region, anoxia pervaded the ocean depths.

Oceanic anoxia preceded the EPME but questions remain about the degree and timing within and across ocean basins. Onoue et al. examine the mid-oceanic geochemical signature of pelagic, deep-sea facies from along the lower flank of a midPanthalassan seamount now exposed in central Honshu, Japan. Here, they evaluate a suite of major, trace, and redox-sensitive elements recovered from a bedded chert/siliceous claystone succession, beginning in the Middle Permian into the Lower Triassic. During this superanoxic interval (Isozaki, 1997), a three-stage increasing pattern of redox-sensitive enrichment beginning $\sim 8$ my prior to the EPME, around the Guadalupian-Lopingian boundary. It culminated in the third enrichment phase coincident with the PTB. Onoue et al. propose that this final enrichment phase resulted from increased sediment discharge of continental weathered landscapes, in response to a temperature rise ca. $200 \mathrm{kyr}$ before the EPME. A similar trend is identified at Meishan, China.

The shallow marine carbonate deposits at Meishan, China, represent the "golden spike" PTB, a Global Stratotype Section and Point (GSSP), and has been the focus of multidisciplinary studies for several decades. Dudás et al. add to these studies by presenting a high-resolution data set of major and trace elements across $2.5 \mathrm{~m}$ where $\sim 75 \mathrm{kyr}$ of the Permian and $\sim 335 \mathrm{kyr}$ of the Triassic are conserved. These authors provide a bed-by-bed analysis of the turnover from carbonate-to siliciclastic-dominated sediments, and which factors and processes may have affected the geochemical values. They conclude that mineralogical changes, volcaniclastic input, and diagenesis, all influenced by varying redox conditions over time, are responsible for the trends. The story associated with the EPME, nor previous extinction intervals, is not simple, nor straightforward.

The isotopic ratio of Strontium $\left({ }^{87} \mathrm{Sr} /{ }^{86} \mathrm{Sr}\right)$ is a geochemical proxy used to determine the secular flux of weathered rock products as they are transported and deposited in marine basins. Shifts in the $\mathrm{Sr}$ ratio are equated to changes in weathering rates which, in effect, is a function of climate and tectonics, and serve as proxies of seawater chemistry. In their review article, Kani and Isozaki trace the long-term trends in $\mathrm{Sr}$ isotopes recovered from carbonates, beginning in the Cambrian, and discuss the minima recorded in latest Permian-earliest Triassic deposits. The long-term Paleozoic trend of decreasing values is attributed to the assembly of the supercontient, Pangea, reflected as increased weathering products to the ocean basins. The middle-late Permian records the lowest isotopic values (Capitanian minima) which continue for approximately $3 \mathrm{~m}$.y. This interval is associated with the end of the Late Paleozoic Ice Age and the collapse of the carbonate factory as suggested by an emerging $\delta^{88} \mathrm{Sr}$ isotope ratio. Following global deglaciation, the trend increases. There is a distinct and sharp increase in values approaching the EPME that these authors attribute to increasing global temperature, but they acknowledge that the ultimate driver(s) have not yet been identified.

A new world order followed in the aftermath of the EPME, resetting rules of the biosphere, which led John Phillips to invent the term "Mesozoic" when he created the first geologic time scale (Phillips, 1834). This involved the appearance of modern ray fins (Neopterygians) that dominate our planet's water bodies. Romano presents a review article on the Triassic fossil record and diversification of marine bony fish. Here, he proposes three, alternative and testable hypotheses about the group's diversification relative, or not, to extinction events. $\mathrm{He}$ concludes that the available data support a Neopterygiian diversification that witnessed a series of gradual replacements over the Early to Middle Triassic, as opposed to explosive radiations following extinction events. Romano acknowledges, though, that none of the three hypotheses can be rejected due to the limits of current data.

The report of the sixth Intergovernmental Panel on Climate Change (IPCC; IPCC, 2021) comes 21 years after the panel presented its initial findings. Since then, international collaboration throughout the global scientific community has determined that climate change is dramatically impacting linked Earth Systems (atmosphere, lithosphere, hydrosphere, cryosphere, biosphere). Repercussions across Earth Systems are occurring under a unidirectional warming trend influenced by human activities. The predicted consequences of various near-term, climate-state scenarios range over time spans of decades to centuries. Regardless of the rate of change in atmospheric conditions or climate, or the timeframe over which such an increase occurs, ecosystems across the planet will continue to be perturbed and experience biodiversity loss (Barnosky et al., 2011). It is impossible to predict the extent to which terrestrial and marine ecosystems may be affected, but we can retrodict deep-time patterns to better understand analog states when 
our planet recorded catastrophic biodiversity loss in response to severe global perturbations. Continuing and evolving multi-disciplinary efforts in deep time demonstrate the complicated events that affected the latest Permian biosphere, one of several models for what the future may hold for planet Earth.

\section{REFERENCES}

Barnosky, A. D., Matzke, N., Tomiya, S., Wogan, G. O. U., Swartz, B., Quental, T. B., et al. (2011). Has the Earth's Sixth Mass Extinction Already Arrived. Nature 471, 51-57. doi:10.1038/nature09678

Botha-Brink, J., Codron, D., Huttenlocker, A. K., Angielczyk, K. D., and Ruta, M. (2016). Breeding Young as a Survival Strategy during Earth's Greatest Mass Extinction. Sci. Rep. 6, e24053. doi:10.1038/srep24053

Burgess, S. D., Bowring, S., and Shen, S.-z. (2014). High-precision Timeline for Earth's Most Severe Extinction. Proc. Natl. Acad. Sci. USA. 111, 3316-3321. doi:10.1073/pnas.1317692111

Chen, J., and Xu, Y. G. (2021). "Permian Large Igneous Provinces and Their Paleoenvironmental Effects," in Large Igneous Provinces: A Driver of Global Environmental and Biotic Chamges. Geophy. (Monogr.) 255. Editors R.E. Ernst, A. J. Dickson, and A. Bekker (Washington DC. USA: AGU Publication), 417-434. doi:10.1002/9781119507444.ch18

Erwin, D. H. (1996). The Mother of Mass Extinctions. Sci. Am. 275 (1), 72-78. doi:10.1038/scientificamerican0796-72

Frank, T. D., Fielding, C. R., Winguth, A. M. E., SavaticTevyaw, K. A., Tevyaw, A., Winguth, C., et al. (2021). Pace, Magnitude, and Nature of Terrestrial Climate Change through the End-Permian Extinction in southeastern Gondwana. Geology 49, 1089-1095. doi:10.1130/G48795.1

Gastaldo, R. A., Neveling, J., Geissman, J. W., Kamo, S. L., and Looy, C. V. (2021). A Tale of Two Tweefonteins: What Physical Correlation, Geochronology, Magnetic Polarity Stratigraphy, and Palynology Reveal about the EndPermian Terrestrial Extinction Paradigm in South Africa. Geol. Soc. Am. Bull. V. 133. doi:10.1130/B35830.1

Gastaldo, R. A., Tabor, N. J., and Neveling, J. (2020). Trends in Stable Isotopes and Climate Proxies from Late Changhsingian Ghost Landscapes of the Karoo Basin, South Africa. Front. Ecol. Evol. 8, 432. doi:10.3389/fevo.2020.567109

Isozaki, Y. (1997). Permo-Triassic Boundary Superanoxia and Stratified Superocean: Records from Lost Deep Sea. Science 276, 235-238. doi:10.1126/science.276.5310.235

\section{AUTHOR CONTRIBUTIONS}

RG drafted the editorial overview after consultation with all original editors of the theme issue. YI, EK, RR, and SZS read, reviewed, and suggested text changes to the overview, which are incorporated in the final version.

Ivanov, A. V., He, H., Yan, L., Ryabov, V. V., Shevko, A. Y., Palesskii, S. V., et al (2013). Siberian Traps Large Igneous Province: Evidence for Two Flood basalt Pulses Around the Permo-Triassic Boundary and in the Middle Triassic, and Contemporaneous Granitic Magmatism. Earth-Science Rev. 122, 58-76. doi:10.1016/j.earscirev.2013.04.001

Phillips, J. (1834). A Guide to Geology. London: Longman, Rees, Orme, Brown, Green, and Longman, 139-154.

IPCC (2021). IPCC, 2021: Summary for Policymakers. In: Climate Change 2021: The Physical Science Basis. Contribution of Working Group I to the Sixth Assessment Report of the Intergovernmental Panel on Climate Change. Editors V. Masson-Delmotte, P. Zhai, A. Pirani, S.L. Connors, C.S. PéanBerger, N. Caud, et al. (Cambridge University Press). In Press.

Viglietti, P. A., Benson, R. B. J., Smith, R. M. H., Botha, J., Kammerer, C. F., Skosan, Z., et al. (2021). Evidence From South Africa For a Protracted End-Permian Extinction on Land. Proc. Natl. Acad. Sci. USA 118. doi:10.1073/ pnas. 2017045118

Conflict of Interest: The authors declare that the research was conducted in the absence of any commercial or financial relationships that could be construed as a potential conflict of interest.

Publisher's Note: All claims expressed in this article are solely those of the authors and do not necessarily represent those of their affiliated organizations, or those of the publisher, the editors and the reviewers. Any product that may be evaluated in this article, or claim that may be made by its manufacturer, is not guaranteed or endorsed by the publisher.

Copyright (c) 2021 Gastaldo, Isozaki, Kustatscher, Reisz and Shen. This is an openaccess article distributed under the terms of the Creative Commons Attribution License (CC BY). The use, distribution or reproduction in other forums is permitted, provided the original author(s) and the copyright owner(s) are credited and that the original publication in this journal is cited, in accordance with accepted academic practice. No use, distribution or reproduction is permitted which does not comply with these terms. 